\title{
Economic inequality and institutional adaptation in response to flood hazards: a historical analysis
}

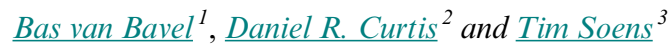

\begin{abstract}
To adequately respond to crises, adaptive governance is crucial, but sometimes institutional adaptation is constrained, even when a society is faced with acute hazards. We hypothesize that economic inequality, defined as unequal ownership of wealth and access to resources, crucially interacts with the way institutions function and are adapted or not. Because the time span for societal responses may be lengthy, we use the historical record as a laboratory to test our hypothesis. In doing so, we focus on floods and water management infrastructure. The test area is one where flood hazards were very evident - the Low Countries (present-day Netherlands and Belgium) in the premodern period (1300-1800) - and we employ comparative analysis of three regions within this geographical area. We draw two conclusions: first, both equitable and inequitable societies can demonstrate resilience in the face of floods, but only if the institutions employed to deal with the hazard are suited to the distributive context. Institutions must change parallel to any changes in inequality. Second, we show that institutional adaptation was not inevitable, but also sometimes failed to occur. Institutional adaptation was never inevitably triggered by stimulus of a hazard, but dependent on socio-political context. Even when vital for the community under threat, adaptation only tended to occur when the vested interests of those with wealth, resources, and power were directly hit.
\end{abstract}

Key Words: adaptation; hazards; history; inequality; institutions; water management

\section{INTRODUCTION}

Environmental hazards and the disasters they can create are no longer seen as simply natural events, but processes that test the capacity of society to organize itself, limit destabilization, and recover (Pelling 2003, Blaikie et al. 2004, Tierney 2007). Disasters are thus social phenomena, where different qualities of societies are crucial in determining coping capacities: absorbing the impact of unforeseen shocks, accommodating their occurrence, and reorganizing to better deal with them in the future (Folke et al. 2005). Success is not only dependent on wealth, technology, and physical infrastructure, but also on the softer qualities of that society, a crucial one being institutional infrastructure and the extent to which this can be adapted (Walker et al. 2004, Folke et al. 2010). A key component of resilience in response to hazards is now said to be the capacity for institutional adaptation (Engle 2011). This is highly relevant in light of recent developments. Although engineered and technological adaptation options remain important in climate change policies, the 2014 assessment report of the Intergovernmental Panel on Climate Change (IPCC) observes a growing awareness of the value of "ecosystem-based, institutional, and social measures" (IPCC 2014:8). At the same time, however, the IPCC acknowledged that adaptive capacities remained highly context-dependent, although we have limited evidence on these "context-specific determinants of vulnerability and adaptive capacity" (Klein et al. 2014:908).

We need, therefore, to better understand how societal characteristics exactly enhance or decrease the capacity to implement effective coping mechanisms and adaptive strategies. Why are some societies capable of institutional adaptation and yet others are not, even when faced with serious hazards? Social capital, social networks, trust, collective action, coordination, education, and training are often singled out as crucial to foster adaptation (Adger 2003, Barnes et al. 2017, Bodin 2017), while mismatches in scale between environmental and social dynamics
(Cumming et al. 2006) and power asymmetries (Crona and Bodin 2010) might hamper or complicate adaptation. However, the number of potential variables is so large, and their relationships so complex, that analysis is difficult. Accordingly, studies often remain descriptive or follow an inductive approach, where a conspicuous aspect of the society in question is privileged as possible cause.

We aim to better understand the role of societal qualities by highlighting two specific ones associated with resilience: (a) formal institutions and institutional adaptation (already often mentioned and investigated in relation to resilience) and (b) material inequality (increasingly mentioned in relation to resilience but not investigated much in literature on the adaptive capacities of socio-environmental systems). We show how the two conjointly affect a society's resilience to hazards and, furthermore, how the effect of one component can only be understood in relation to the other. First, we analyze how material inequality can affect the functioning of the formal institutions and associated organizations needed to cope with storm surges and high water tables, and second we assess to what extent these water management institutions can adapt in the aftermath of floods.

\section{(a) Inequality and resilience}

Research increasingly suggests that material inequality may affect coping strategies or adaptive capacities after hazards. Empirical research, however, is very limited. At the household level the impact of wealth on coping strategies has provided inconclusive results (Hoddinott 2006, Béné et al. 2016). Studies have established a positive correlation between income inequality and increased susceptibility to disastrous outcomes from natural hazards in present-day countries (Castillo and Hillier 2013). When the number of natural disasters is held constant, and controlling for national wealth, countries with less income inequality (as well as more democratic nations) suffer fewer deaths 
from disasters, as observed for a set of 57 countries analyzed for the period 1980-2002, with the effect of income inequality found to be very large (Kahn 2005). However, what is it precisely about inequality that makes a society less able to cope or adapt? Although poverty may hamper adaptive capacities (Carter et al. 2007, Carpenter and Brock 2008), inequalities in the distribution of resources often remain undiscussed. The causal relationship between the two, distribution and resilience, is hidden from view, and remains based on implicit assumption or logical intuition. In this paper, we explore an intermediary phase (institutional configurations) linking the two; that is to say we examine how the distributive context can shape the effective employment of the institutions necessary for societal resilience.

\section{(b) Hazards and institutional adaptation}

Some literature emphasizes a loop-feedback process with a positive outcome, whereby environmental hazards become the stimulus or trigger for institutional adaptation, and this institutional adaptation increases societal resilience to future hazards (Kaufman et al. 2016). However, this may also be at odds with other literature that is skeptical about the "inevitable" adaptation response. Some socio-environmental systems were trapped in a feedback process where external triggers (such as climate hazards) interacted with key system variables in preventing the flexibility needed for adaptation (Cinner 2011, Enfors 2013). Apart from these rigidity traps, it has been observed that institutions are not automatically geared toward the goals of coping or recovery, nor inevitably designed for conservation purposes per se (Fabinyi et al. 2014). Moreover, institutions devised to tackle one challenge may have unforeseen side-effects (positive or negative) in other domains. In fact, some suggest that institutions are to a large part the result of social bargaining or even conflict, and intimately link up with the leverage and positions of social actors. That being so, they may be formed and manipulated by the interests and preferences of certain individuals and social groups holding inequitable amounts of power, resources, and social capital (Nee and Ingram 1998, Ogilvie 2007). In this paper, we examine to what extent environmental hazards automatically lead to institutional adaptation, and if not, focus on some of the reasons why this may not be so.

Overall, we provide two hypotheses. First, we suggest that economic inequality, defined as unequal ownership or use of resources, especially affects societal responses to hazards by impacting upon the development and use of institutions. Second, we suggest that institutional adaptation may not inevitably occur in the aftermath of hazards, as a result of power asymmetries, or more precisely, a mismatch between the broader needs for societal resilience and the needs of a more select group with focused interests. To test these hypotheses we focus on (a) inequality in the distribution of resources, (b) formal water management institutions, and (c) floods, all tested within the geographical and temporal context of the preindustrial Low Countries (12501800).

\section{METHODS}

We employ a historical approach. This allows us to discuss temporal dimensions, including those in the very long run. The relationships between inequality, institutions, and adaptation discussed here developed over time, did not necessarily move in one direction, and societal responses were often lengthy, necessitating the use of the historical record (van Bavel and Curtis
2016, Rohland 2018). The historical record also offers a wide variety in levels of inequality, institutional arrangements, social characteristics, and flooding outcomes, which were often importantly found at a regional level, sometimes even regions close together subject to the same kinds of exogenous shock (Curtis et al. 2016). The regions considered in this paper are not so much defined by size or geography, but rather by their internal coherence in socioeconomic, institutional, and environmental features. This variety of configurations at the regional level hence presents a suitable laboratory for developing and testing ideas at the macrolevel over the long run (van Bavel 2015).

This regional variety in institutional arrangements is particularly evident in the field of water management in the preindustrial Low Countries. In many coastal and riverine areas, water management was organized by autonomous organizations or decision-making bodies, organized along local or regional lines, which set the formal rules and decided on the extent and nature of investments. (Soens 2013a). Although decision-making processes were sometimes very localized, i.e., organized per village or group of villages, and sometimes centralized in supra-local water boards covering 20 villages or more, such as the one founded in 1327 in the Tielerwaard and Bommelerwaard in the Guelders river area (Moorman van Kappen et al. 1977), major changes in the level of investments, the inclusiveness of the decision-making process, or the organization of funding generally showed significant regional coherence (Soens 2011). Moreover, although central political bodies existed at the supra-regional or state-level (van Cruyningen 2014, van Tielhof 2015), they had limited influence before 1800: the local/regional water management bodies were decisive in supervision, taxation, and investment.

Social characteristics in the preindustrial Low Countries also varied sharply per region, even among neighboring regions (van Bavel 2010). Each region had specific characteristics in its distribution of property and resources, social relationships, and constellations of institutions. Regional differences were pronounced in the countryside, and more so than in the towns where inter-regional interaction and convergence were more apparent. Because water management organization was a rural phenomenon, we employ the different institutional organization of water management, extents of economic inequality, and flooding outcomes, to better understand the effect of economic inequality on the adaptive capacity of institutions to limit the negative impact of hazards and shocks. Furthermore, the temporal dimension allows us to identify any changes over time, giving us a double opportunity for comparison: between regions and across periods within regions.

We analyze three regional rural societies where the threat of floods was high over a long period to identify different phases in the interaction between material inequality, institutions, and floods (Fig. 1). All over the North Sea area the social-ecological transformation of coastal wetlands from extensively used floodplains into settled landscapes set in around $1000 \mathrm{CE}$ and had been more or less completed by the moment we start our analysis in $1250 \mathrm{CE}$ (Rippon 2000). From the moment coastal wetlands were reclaimed through the construction of sea-walls or dikes they became vulnerable to dike breaches and floods, which usually were triggered by storm surges, combinations of severe storm conditions and high tides. Although some periods witnessed a higher frequency and intensity of storm surges than 
Fig. 1. Map of the Low Countries indicating the three regions. Iason Jongepier, GIStorical Antwerp (UAntwerpen/Hercules Foundation).

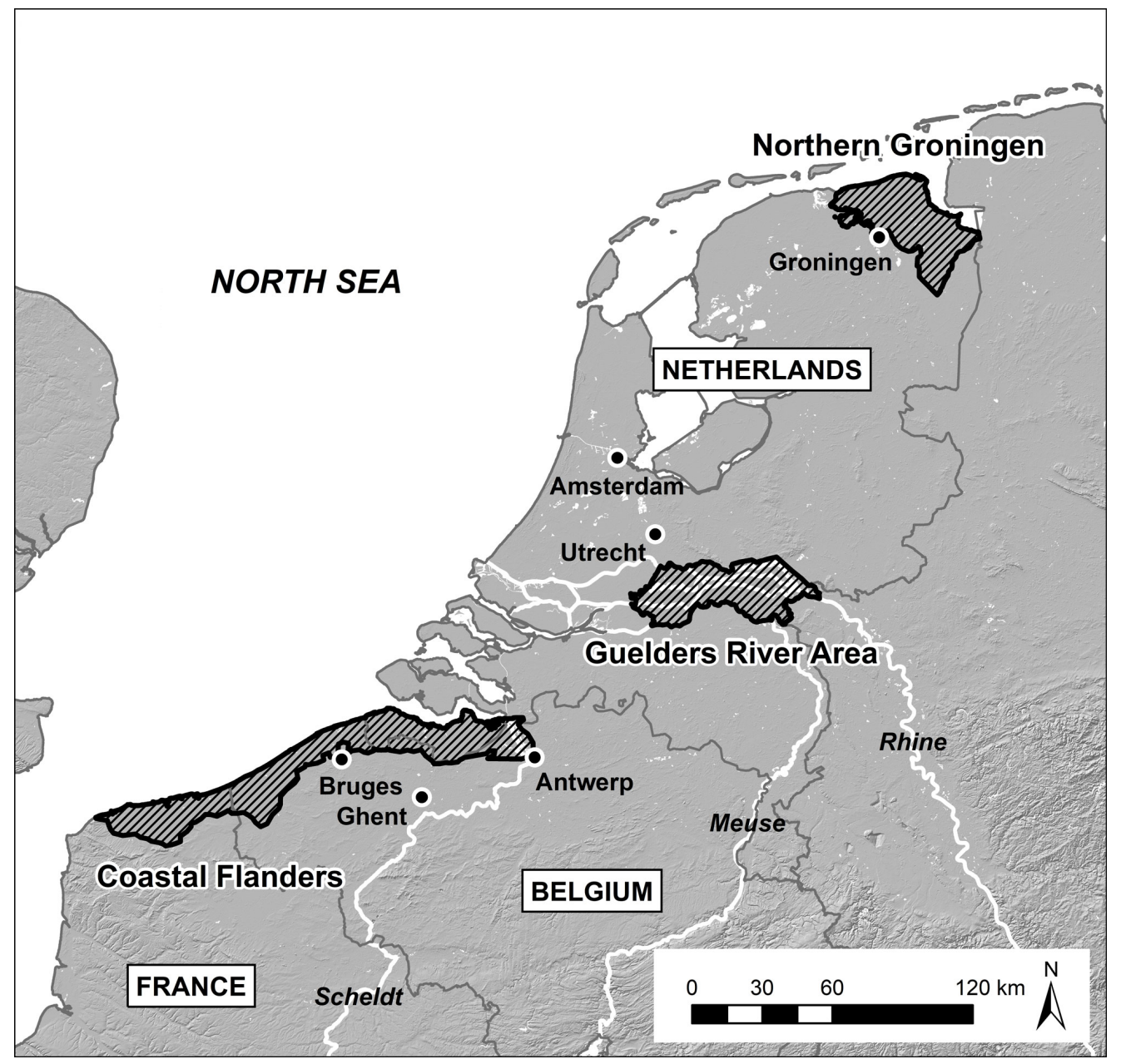

others, related to changes in atmospheric patterns over the North Atlantic (Dangendorf et al. 2014, Suursaar et al. 2015, Degroot 2018), no causal link between variations in storminess and the chronology and geography of coastal floods can be established (de Kraker 2013). Likewise, a meticulous reconstruction of water discharge quantities of the River Rhine at Basel from 1268 onward (Wetter at al. 2011), indicative of the hazard posed to the lower basin of the River Rhine, does not correspond to the occurrence of large floods in the lower regions. Although floods were triggered by major storm surges or large water discharges, not every major storm surge or peak discharge produced a flood. So although we cannot control exactly for the occurrence of storm surges or rainfall and the deeper environmental dynamics underlying these surges, significant variations in the occurrence and intensity of floods that were unrelated to chronologies of storminess or water tables suggest that societal factors had an important role to play.

We have selected societies where significant changes occurred in inequality or the institutional organization of water management and where we have sources available to reconstruct these. The three societies in the Low Countries include (a) Coastal Flanders,
1250-1570, (b) the Guelders River Area, 1400-1700, and (c) Northern Groningen, 1500-1800. For each of the three cases we analyze changes in inequality, the institutional organization of water management, and flooding outcomes.

We make the reconstructions on the basis of secondary published material for each case, supplemented by additional primary source research. For economic inequality, we measure the distribution of land because this was the most important production factor and wealth component in Northwest European preindustrial rural societies. Fortunately, this is also best documented because taxation was mostly levied on land and left most traces in the sources. Indeed, the main primary sources used include fiscal documents and property registers such as lease books, which for these three societies are relatively abundant and accessible, and therefore another reason to select these three cases.

We measure inequality both for the ownership of the land (the distribution of land over the owners) and the access to the use of the land (the distribution of land over the users). Because substantial shares of the land were leased out, and thus could be accumulated or fragmented through the lease market, distribution 
at the user level could differ from that at the ownership level. We measure land ownership as changes in the percentages distributed between different social groups (the aristocracy, urban burghers, farmers, and peasants); that is to say an increased proportion of property moving out of the hands of local peasants and into the hands of absentee urban burghers is an indication of heightening inequality. For land use within the rural communities, the sources allow us to calculate Gini coefficients property distribution at the user level, which range historically in late-medieval and early modern Western Europe from lows of roughly 0.4 to highs of roughly 0.9 (Curtis 2014a). Of course, each source for each region has its own idiosyncrasies, which mean that it is difficult to compare inequality levels between regions in any absolute terms. Whereas in Groningen the fiscal records are measuring distribution of land farmed by all users (whether they are direct owners or tenants), the data we have for the Guelders river area mostly relates only to distribution of land between lease tenants, and we cannot fully compare the two. We accept this, and instead use the Gini coefficients as relative indicators, measuring changes in distribution of land in the individual regions themselves over time (for the same approach employed in other recent historical studies on long-term changes in inequality, see Alfani and Ammannati 2017). Although the Gini mainly measures extremes (rather than middling groups), this is appropriate for our purposes because we are mainly interested in the effects of pronounced polarization. Overall, we try to keep the same unit of measurement across time, however because of historical source limitations, sometimes the inequality figures come from the whole region under study, but sometimes (especially for earlier periods) from a subsample of the region, i.e., some villages within the region. Finally, it must be noted also that although these sources do not record the landless, the fiscal records at least register those people who had a tiny plot, just large enough for a small cottage or hut and garden. The proportion of people who did not even have a small plot for a residence, however meagre, was likely very small, and thus accordingly, the proportion of people not accounted for is also small.

The reconstruction of the institutions for water management is more straightforward and occurs through piecing together information from an assortment of account books and statutes from water boards. The Low Countries offer some of the world's oldest continuous series of account books related to flood protection and drainage, starting as early as the late 13 th century. Investments related to the upkeep of the water management infrastructure were substantial, and could vary from five to more than $30 \%$ of the annual income from land (Soens 2011). The same sources, complemented by statutes, legal proceedings (lawsuits), and, from the 16th century onward, minutes of meetings, also provide data on the decision-making process, for instance allowing us to investigate the rotation and social background of office-holders as proxy for the inclusiveness of the decisionmaking process (Brusse 2018).

Finally, we measure the outcome variable as the severity of the flooding. To begin with, we use chronicles and other forms of administrative documents to simply reconstruct the incidence of flood events. Our task here is aided by the extremely detailed archival work already created on the subject, where a threevolume gazetteer was produced, practically reconstructing every single flood ever to have occurred in the preindustrial Low Countries (Gottschalk 1971, 1975, 1977, revised and supplemented by Buisman 1995-2015). However detailed these gazetteers might be, they do not allow for a simple quantification of flood frequency: on the one hand the records clearly are less abundant before 1400 than after, on the other hand, more localized flood problems might be recorded in one case, but omitted in another. Moreover, the simple occurrence or frequency of a flood is also insufficient in itself to determine whether a certain social-ecological arrangement lacked resilience qualities or not. Indeed, throughout history there are many examples of societies that faced periodic flood episodes without major social, economic, or political disruption (Endfield 2012), or even benefitted from floods, as, for example, in using deposited sediment as fertilizer (Smith 2014). Accordingly, we also account for the different harmful effects of the flood in question. The first marker we use is number of casualties. Generally speaking, preindustrial and modern floods in northwest Europe have very low mortality effects (Soens 2018), and thus any flood that did produce high casualties, can automatically be considered as severe. By this we assess any floods as severe if they produced more than 500 casualties in the whole area under investigation (given that only a few floods have ever produced more than 1000 total casualties in the whole of the North Sea area: JakubowskiTiessen 1992, Buisman 2015), or if within a locality in the area, there was a mortality rate of more than $20 \%$ of the resident population (and therefore over the same threshold determining a severe preindustrial epidemic or famine: Alfani and Ó Gráda 2017). Quantifiable figures are possible for many of the early modern floods, and from the 17th century onward, much more specific mortality information for certain localities can be provided through burial registers, which allow us to place flood casualties in relation to normal numbers of deaths. However, for the medieval period in particular, but also some of the early modern floods, information on casualties is either missing or subject to inaccuracy and unreliability (Curtis 2014a). Accordingly, our second indicator for severity of a flood episode is measured through the impact on the most important production factor in these preindustrial societies: land. More specifically, we look at loss of land, land falling into a state of disuse, land no longer able to be intensively used, or loss of capital goods and infrastructure needed to work the land. This information can never be fully complete because we are dependent on the availability of sources, but we have used all relevant and accessible information from an assortment of documentary source material including chronicles and narrative observations, state resolutions, and water board petitions. It must be noted that this indicator of land loss and capital damage does not always mean the same thing between different historical societies, e.g., the repercussions of 100 hectares loss via flooding in one region is not always equivalent to the same 100 hectares loss elsewhere, and thus this indicator is only compared temporally within the same region rather than between regions. Overall then, all of the above allows us to assess flood periods in four categories: infrequent low severity, frequent low severity, infrequent high severity, and frequent high severity.

\section{RESULTS}

\section{Coastal Flanders, 1250-1570}

The Flemish coastal plain, which geographically stretches from Calais in Northern France over the Belgian coast to Zeelandic Flanders (today part of the Netherlands; Fig. 2), was largely 
Fig. 2. Map of coastal Flanders, indicating the localities mentioned in the text. Iason Jongepier, GIStorical Antwerp (UAntwerpen/Hercules Foundation)

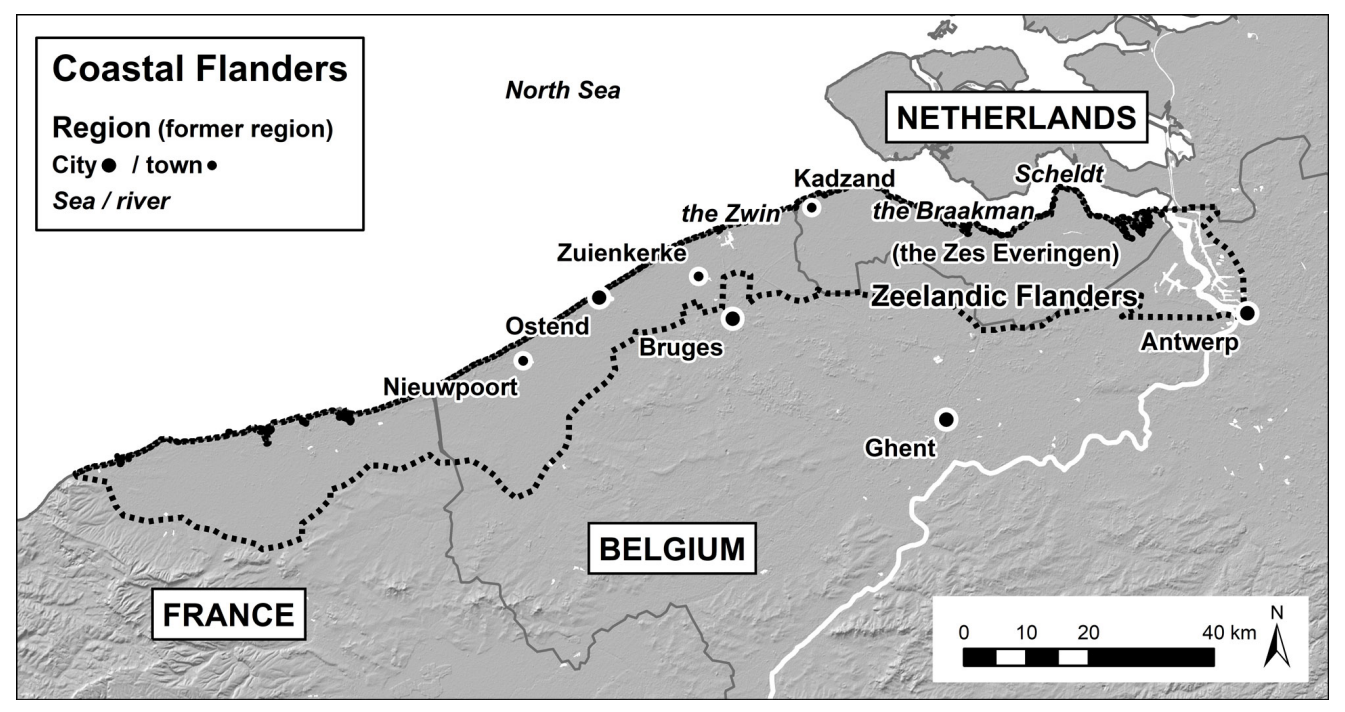

reclaimed between the 10th and the 13th centuries, when the previous strategy of living on higher lands or raised mouths and concentrating on animal husbandry was abandoned in favor of permanent embankment and drainage (Soens et al. 2014). Most of the area was situated above mean high water, but remained liable to flooding due to periodic storm surges, the humaninduced erosion of the old dune barrier protecting the coast, and the shrinkage of the peat soils in the interior parts of the coastal plain.

\section{0-1350: Low but rising inequality in landownership and land use, institutional adaptation, unknown frequency, low severity flooding}

The initial reclamation of the area was probably initiated by communities of free peasant farmers. From the 11th century onward, however, common salt marshes near tidal channels were increasingly appropriated by the Count of Flanders, who donated parts to ecclesiastical institutions and noble families. Settlers were attracted by favorable conditions of tenure, including personal freedoms and political autonomy (Tys 2013). In the 12th and 13th centuries Coastal Flanders witnessed remarkable economic and demographic growth in conditions of relative equality, with nonspecialized smallholders engaging in proto-industrial and para-agrarian activities such as fishing and salt extraction. By the 13th century, the coastal plain was inhabited by landowning peasant smallholders. In 1227 for instance, the polder of Stoppeldijk ( 694.5 hectares of land) was owned by 172 local landowners, owning on average four hectares of land each. Only three local noblemen owned more substantial plots of land (between 25 and 40 hectares each; Soens 2009). In contrast, the 13 th century saw a pronounced rise in inequality of landownership resulting from peasant expropriation and land grabbing by bourgeois, noble, and monastic landowners: the first surveys of landownership dating from the late 14th century indicate that 40 to $45 \%$ of the land north of Bruges was owned by these absentee landowners (Soens 2009), and much of this land was acquired from the local peasantry between 1250 and 1350, as documented by a huge number of land transfers (sales, gifts, and confiscations) dating back to this period. (Soens and Thoen 2008). In some cases whole districts (polders) were sold by their former peasant landowners, including the already mentioned polder of Stoppeldijk, which in 1227 was sold by its 172 landowners to one single owner: the Cistercian Abbey of Cambron. At the user level, we see a polarization of land use, with on the one hand some land turned into larger farmsteads, and on the other increasing pressure on the market for small plots of land. The multiplication of these microholdings (below one hectare) resulted in high inequality of land use already around 1300 (with for instance a Gini coefficient for the distribution of lease land of 0.63 among the 88 tenants on the Zuienkerke-estate of St John's Hospital in Bruges in 1310; own calculation based on Appendix in Vervaet 2015).

The organization of coastal flood protection was gradually adapted to these changes in economic inequality. Starting in the surroundings of the city of Bruges, the commercial gateway of late-medieval Flanders, maintenance shifted from individual landowners to specific local authorities, the water boards, which hired labor and levied a monetary tax proportional to the land owned to finance their activities. By the end of the 13th century coastal flood protection in Flanders had been monetized, a radical institutional transformation that allowed the rapid mobilization of capital after floods and adapted coastal water management to a new social situation in which absentee landowners controlled a large part of the land (Soens 2009, 2011). Whether these institutional changes were linked to any particular flood episode is uncertain: Gottschalk (1971) mentions seven flood episodes in this period, but this is probably an understatement (Galloway 2009). In any case, the highly adaptable water governance of this period was rather successful in preventing storm surges turning into full-blown flood disasters. The so-called Clemens Flood of 23 November 1334 caused dike breaches all over the Flemish North Sea Coast and the Scheldt Estuary, but the damage was swiftly repaired, including adapted organization of settlements, 
for instance, in the town of Ostend where the church was relocated to a higher place (Augustyn 1992). Notwithstanding difficult political and economic circumstances that included FrancoFlemish warfare, the Great Famine of 1315-1317, and the Peasant Revolt of 1323-1328 (TeBrake 1993), overall land losses remained limited.

\section{0-1425: Stable inequality of landownership but decreasing inequality of land use, institutions not adapted, frequent high severity flooding}

After the population decline caused by the Black Death and recurring plagues, Coastal Flanders experienced a reduction in the number of microholdings (smaller than 1 hectare), but an increase in smallholdings (3-5 hectares) and middle-sized holdings (5-15 hectares). With a Gini coefficient of 0.55 in 1369 (compared to 0.63 in 1310) and a median landholding of 1.16 hectares (compared to 0.76 in 1310), the inequality of land use on the above mentioned estate in Zuienkerke was clearly decreasing (own calculation based on Appendix in Vervaet 2015). Real wages for both skilled and unskilled workers increased considerably in the post-Black Death period, and this rise was more pronounced in the coastal plain than in other parts of Flanders (Thoen and Soens 2015). As coastal agriculture remained labor-intensive, demand for labor was high, resulting in a true golden age for wage labor, lasting until the 1420s (Geens and Soens 2017, unpublished manuscript). Fiscal data from the latter decade, mainly based on the income from land, and hence reflecting inequality of land use, testify to a relatively equal society (a Gini coefficient of 0.42 in the village of Zuienkerke in 1425; Dombrecht and Ryckbosch 2017). In contrast, the allocation of landownership remained more stable: the gains made by large absentee landowners in the previous period were consolidated, but no longer expanded, meaning that 50 to $60 \%$ of the land was still owned by the local peasantry (Soens 2009).

In Coastal Flanders, this post-Black Death period was characterized by several devastating storm surges (14 according to Gottschalk 1971) and at least two of them can be classified as very severe following our criteria. Although the number of casualties probably remained limited (Soens 2018), the storm surges of 8 to 10 October 1375 and 19 November 1404 resulted in major land losses, which could not be undone over the next decades. The floods of 1391 and 1424 resulted in more localized land losses. In 1408, the permanent land losses along the Flemish North Sea coast between Nieuwpoort and Kadzand already totaled 3025 hectares, as estimated by officials of the Count of Flanders, and included both submerged lands and lands destroyed by inland drifting sand dunes (Augustyn 1992). In the Western Scheldt Estuary, a new tidal inlet was created, the Braakman, leading to the permanent loss of at least 10 parishes (Gottschalk 1975). In reaction to these repeated flood disasters, Flemish water boards showed little sign of adaptation: they tried to absorb floods in exactly the same way as before, investing large amounts of money, used to hire large numbers of laborers (Soens 2011). Although wages were higher after the Black Death, the financial cost of not adapting was also high. This burden of taxation eventually proved problematic for the remaining landowning peasantry, who had to pay taxes with the profit of their marketable surpluses in a period when food prices were low. The changed social conditions of the post-Black Death period required a return to maintenance based on labor duties, rather than sticking to the monetized system introduced in the late 13th century. Although the coastal peasantry still enjoyed some form of access to the decision-making process (Soens 2009), they lacked the kind of political leverage needed to force major institutional adaptations upon the absentee landowners.

1425-1570: Increasing inequality of landownership and land use, limited institutional adaptations, frequent low severity flooding Between 1425 and 1550 a massive transfer of landed property took place from the peasant population to absentee landlords. The urban bourgeoisie as well as the nobility and ecclesiastical landlords, which in Flanders also were predominantly townbased, saw their combined share in the ownership of coastal land increase from 30 to $40 \%$ around 1300 and 1400 to 60 to $70 \%$ around 1550 (Soens 2009, Dombrecht and Ryckbosch 2017). This produced a constant flow of rent from the coastal wetlands to the city, further sharpening the material inequalities between an increasingly landless farming population and mostly absentee landlords. At the same time, land use went through a process of engrossment, with large farms (above 20 hectares) now controlling $70 \%$ of the land or more (for instance in the village of Oostkerke in 1570, Soens 2009). Because this was paralleled by a further decline in the number of microholdings, the Gini coefficient for the distribution of lease land did not change much ( 0.54 to 0.56 on the above mentioned estate of St John's Hospital in Zuienkerke; own calculation based on Vervaet 2015). However, these data exclude the growing number of landless laborers and cottagers only renting a house and garden. Only for Hulsterambacht in the north of Coastal Flanders, is a more comprehensive overview of land use, including cottagers and landless laborers, available. A Gini-coefficient of 0.66 among the 1233 land users in the area around 1570 clearly confirms a rising polarization of land use (own calculation based on Nijenhuis 1992).

The organization of flood protection in Coastal Flanders did not witness fundamental changes. However, as peasant landownership gradually declined, large landlords consolidated their grip on the water boards, effectively ending the long tradition of inclusive decision making in coastal water management. From the mid-15th century onward, landlords opted for austerity by reducing expenditure on flood protection to increase the financial return on their land (Soens 2011). Although dike breaches were frequent (Gottschalk 1975 records 35 floods in this period), the emphasis on cost-efficiency initially succeeded in preventing these floods from turning into severe flood disasters: after 1425, coastal Flanders witnessed few permanent land losses. Only in 1488, seven parishes were permanently flooded in the Braakman area, resulting in a land loss of between 11,000 and 13,000 hectares, but this land loss is widely attributed to the civil war ravaging Flanders from 1488 to 1492, resulting both in deliberate, so-called strategic inundations and a delay in the repair of relatively minor breaches (de Kraker 1997). Flood problems gradually increased in the 16th century, with supra-local floods in 1509, 1511, 1530, 1532,1552 , and 1570 . The death count of these floods remained limited, in contrast to other regions like Northern Groningen in 1570. For 1509 and 1511, de Kraker (2015) estimated that about $10 \%$ of the Zwin region north of Bruges was flooded, but hardly any land was permanently lost to the sea. In 1530-1532 about 14,500 hectares were flooded east of the Braakman, but again only 8 or $9 \%$ of the land could not be recovered immediately (de 
Fig. 3. Map of the Guelders river area, indicating the localities mentioned in the text. Iason Jongepier, GIStorical Antwerp (UAntwerpen/Hercules Foundation)

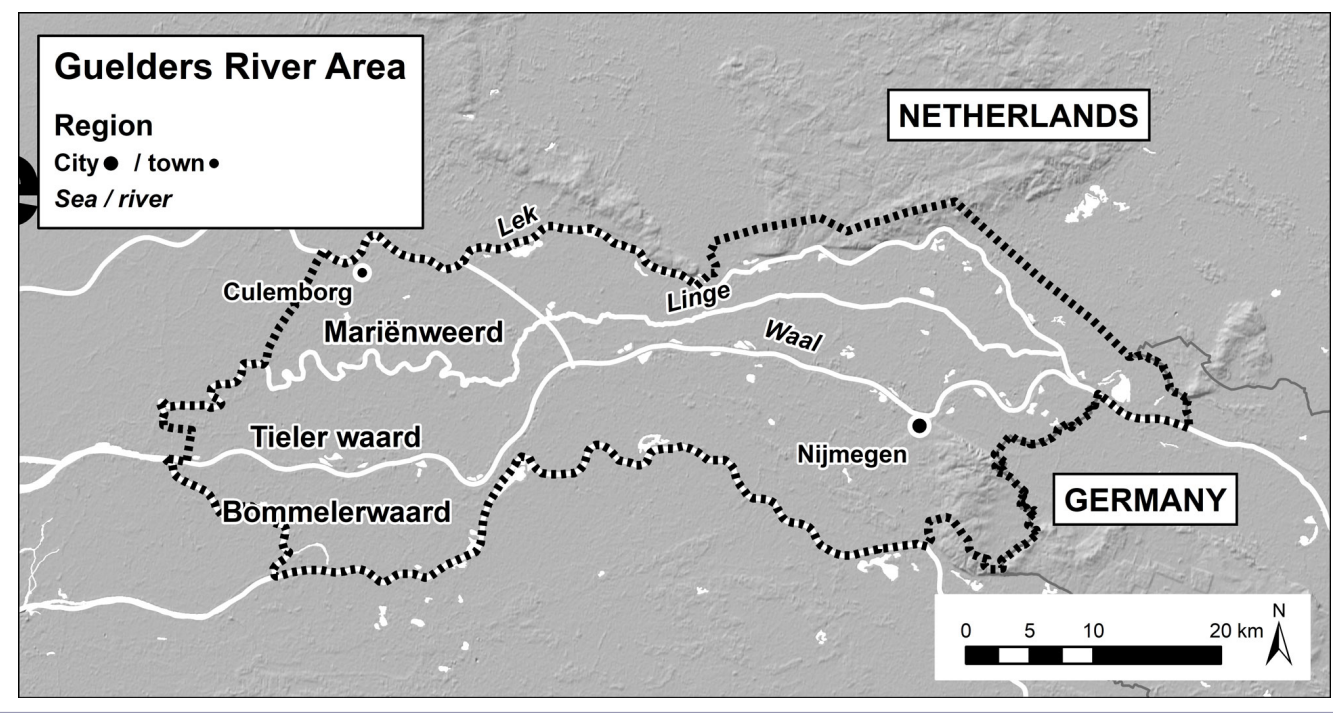

Kraker 1997), mainly thanks to the influx of merchant capital from the booming metropolis of Antwerp (Dekker and Baetens 2010). By this time, however, there was a clear feeling that austerity policies had reached their limits: there were widespread calls to change the localized funding mechanisms of flood protection, and enforce the solidarity of a wider hinterland with areas threatened by floods. This only succeeded in a limited number of cases, triggered by a major flood - Kadzand after 1530-1532 and the Zes Everingen after 1552 - and the direct intervention of the Habsburg Monarchy (de Kraker 1997, van Tielhof 2015). Overall, however, the vested financial interests of large landlords worked against major institutional reforms toward broader financial solidarity (Soens 2013b). Although floods were not particularly severe in terms of permanent land losses or casualties, they did reinforce inequality: with every flood more land was transferred from local landowners to absentee investors (Dekker and Baetens 2010).

\section{Guelders river area, $\mathbf{1 4 0 0 - 1 7 0 0}$}

This area was continuously exposed to the hazard of flooding because it was crossed by three large rivers (Fig. 3) and most land was low-lying, even more so as the drainage of agricultural land from the 11th century had led to soil subsidence. Risk was further intensified by diking, leading to sedimentation and ever higherlying rivers, especially when the dikes were fully completed in the late-13th century. This increased the chances and severity of dike breaks and floods, and problems with the seepage of water made it a risk-prone area.

\section{0-1440: High inequality of landownership and relative} equality of land use, changing institutions, frequent high severity flooding

The region had almost no independent small-scale peasant landowners because it had been dominated by the large estates of noble and monastic owners since the early Middle Ages. About four-fifths of the land was, and remained, owned by a small number of noblemen and religious houses and the region was thus characterized by high inequality at the ownership level (van Bavel 1999). These large estates in their turn were divided up into smaller parcels and leased out for short terms from the 14th century onward in a competitive lease market. In the first half of the 15th century, this lease land was still distributed broadly between tenants with family-sized farms, thus creating a relative equality at the land-user level, as most people had access to a family-farm, even if they were not owners.

Whereas earlier water management was organized by local communities, the linking of dike systems around 1300 required supra-local cooperation and invited top-down interference by the Count of Guelders, although local communities and lords still played major roles (Moorman van Kappen et al. 1977). Around 1400, this institutional organization was rearranged. Maintenance was divided between the villages, who now became responsible themselves for the division of tasks between individuals, with specific sections of the dike allocated to the owners of specific parcels (Moorman van Kappen et al. 1977). In this period, however, many of these individuals abandoned their parcels burdened with diking duties, leading to increasingly dangerous situations. In reaction to this, in the period 1410-1414, the duties were made common: that is the local water management authorities decided on maintenance, and costs were divided between landowners according to the size of their estate in the area protected by the dike. This led to a monetization of water management duties, which pressurized landowners interested in keeping costs down.

Documentary evidence to reconstruct the incidence of floods is scarce in the 14th century, but becomes richer from the closing decades of that century. Still, not a single river flood in the area is recorded. The period 1400-1440, on the other hand, saw various floods recorded by chroniclers, who tended to reflect on their severe nature (in 1409, 1413, 1432, 1433, and 1438; Gottschalk 1975, Kuys et al. 1983). After the breach of the dikes along the river Waal in 1432, destroying the sown winter grain, dikes broke 
again in the winter of 1433 , flooding the whole region. The water was so high that people had to take refuge on the tops of their houses, where many died of cold or hunger (Buisman 1996 Vol. II). The large landowning abbey of Mariënweerd lost most of their winter grain when the Linge dike broke, and lower-lying areas reclaimed from the marshes stayed under water for consecutive years in the 1430s (Curtis 2014a). In 1437, again, the dikes along the Waal broke three times, causing destruction, also of capital goods, including the stoned ovens of the town of Culemborg $^{[1]}$. This period thus stands out for the severity of floods, indicating that the changes in institutional arrangement either misfired or led to transitional problems.

1440-1520: Stable high inequality of landownership and stable distribution of land use, stable institutions, infrequent low severity flooding

In this societal context, the distribution of landownership and land use did not change much. Most land remained in the ownership of the same large landlords, while most of the farms continued to be leased by family farmers and remained composed of a scattered patchwork of smaller plots. In 1456, the Gini coefficient for distribution of lease land was 0.74 in the western part of the Guelders river area (Curtis 2014a): rather unequal for distribution at the land-use level but relatively equal compared to the distribution of landownership and compared to the distribution at the land-use level later in the 16th century. The institutional organization of water management underwent no changes in the period. Parts of the duties were performed by the tenants of the family farms in the form of labor, and other parts in money paid by tenants and landlords.

Whereas the previous period was characterized by massive floods, this period was a lengthy phase with only a few floods up to c. 1520 . Despite the full and extensive documentary evidence for this period, including that of several very detailed chronicles for the area, only five dike breaches leading to flooding are recorded in this 80-year period: in 1469, 1486, 1497, 1511, and 1519 (Gottschalk1975). They do not appear to have had any significant impact on land, capital goods, and production, but only caused some temporary nuisance and required some labor and investment to repair dikes, as from the burghers of Nijmegen in 1511, who had helped in repairing the dike on the river Waal and were rewarded with six barrels of beer. The low frequency of floods and their minor severity reflects a well-functioning mixed system of water management (owner/tenant; money/labor; local/ regional) within a stable societal and environmental context. The fact that the system performed well suggests retroactively that the major flood incidence of the previous period was due to transitional problems, and not fundamental ones.

\section{0-1560: Stable high inequality of landownership and growing} inequality of land use, no adaption of institutions, frequent low severity flooding

In this period, the Guelders river area underwent a conspicuous process of rising inequality; not at the landownership level, where the distribution had always been highly unequal, but at the landuser level. In a process accelerating in the 16th century, the sharp competition in lease markets and in output markets gave rise to a small group of large tenant farmers who accumulated lease land, formed large capital-intensive farms, and pushed small- and medium-scale tenants out of the market. About $40 \%$ of the land came into the hands of farmers using 30 hectares of land or more, while these large farms had been virtually absent before (van Bavel 2001, Curtis 2014a). Whereas in 1456 the distribution of tenant land in the western part of the Guelders river area had a Gini coefficient of 0.74 , in 1550 it had risen to 0.85 (Curtis 2014a). These farms focused on extensive pastoral farming, while medium-sized farms that had previously focused on arable agriculture disappeared.

Institutional arrangements were not adapted in this period. Their effects, however, did change as a result of rising inequality. As small-scale tenants disappeared, water management became more monetized, with many labor duties replaced by payments in money, used for hiring wage laborers. The costs were mainly shifted from landowners to tenants by way of stipulations in the lease contracts, with sharp competition for lease land forcing tenants to accept the terms. The few remaining small-scale tenants, often in financial trouble, became burdened with very onerous labor tasks and were made responsible for relatively large tracts of the dike. Also, in this now fully market-oriented environment, in which neither tenants nor wage laborers had any say in decisions on water management, the large landowners decided themselves on investments and regular maintenance with an eye on profit margins. This led to increasing focus on investments in watermills for drainage purposes, as this pushed up productivity, and a neglected construction and renovation of dikes. Around 1520, a special tax for tenants was introduced to finance drainage mills, with the tax rate doubled in 1532 and again raised by half in 1559 (van Bavel 1993).

In the context of growing inequality, floods returned again. These floods were not catastrophic or permanent land losses, but they were serious, and their large number is especially striking, with no fewer than 10 serious ones in this 40 -year period. The largest landowner in the region, the Abbot of Mariënweerd, noted heavy damage following a large flood in February 1551, with the land under several meters of water, but damage became even greater when the water returned in May of the same year, rendering it impossible for the farmers to graze their cattle and sow their lands. The severe impact is reflected in the fact that the abbot granted the tenants reductions of half or even the whole lease sum (Gottschalk 1975, van Bavel 1993). This flood was exceptional in its impact, but the number of floods in this period was large.

Floods and semipermanent problems with water contributed to growing inequality at the land-user level as a feedback loop. First, it contributed to the growing precariousness of small-scale tenants, together with the ravages brought by war, as evidenced by their increasing indebtedness around the middle of the 16th century (van Bavel 1993). Second, it made intensive arable agriculture impossible in large parts, contributing to a development toward extensive forms of animal husbandry, most notably breeding of horses and fattening of oxen (van Bavel 2001). These sectors were capital-intensive, required capital reserves and solid links to financial and output markets, and required very little labor, thus exacerbating the problems of small-scale tenants and reinforcing the position of large-scale wealthy tenants. These were also the ones, conjointly with the large landowners, who dominated decisions on water management and did not have an incentive to fundamentally adapt the institutions of water management. 
Fig. 4. Map of Northern Groningen, indicating the localities mentioned in the text. Iason Jongepier, GIStorical Antwerp (UAntwerpen/Hercules Foundation)

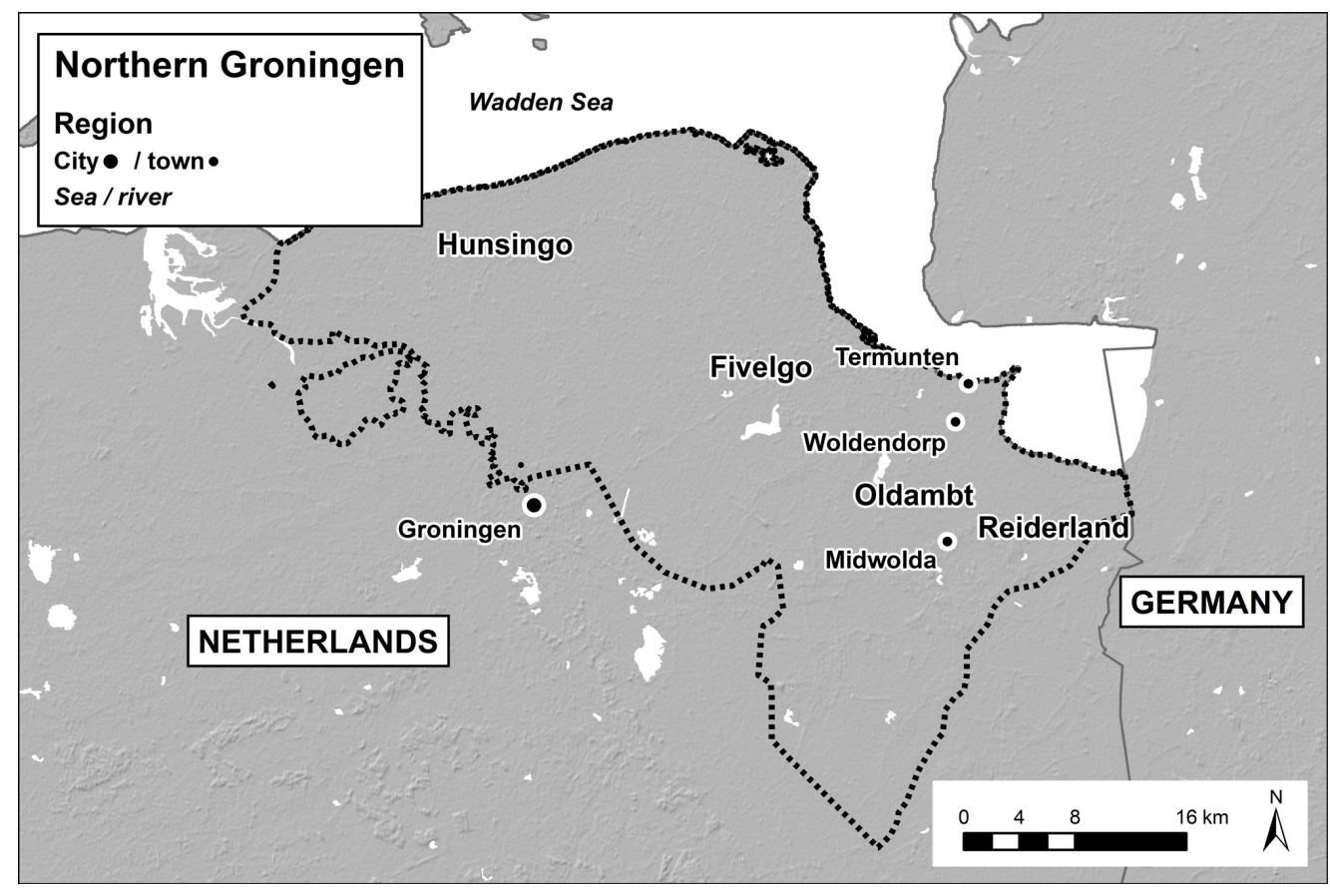

1560-1700: Stable high inequality of landownership and land use, hardly changing institutions, frequent high severity flooding Around 1600, land remained highly unequally distributed, both in landownership, as it had always been, and now also at the user level, apart from small pockets of small-scale farming (Brusse 2018). Also around 1600, central authorities attempted to replace local and regional rules and customs in water management by a more centralized regulatory system (Moorman van Kappen et al. 1977). These attempts largely failed, as a result of local communities and lords clinging to their traditional roles. As the necessity of cooperating in large investments increased, this increasingly became problematic, as particularistic tendencies prevailed. Within this institutional system, the weight of money payments quickly increased from c.1560. As a share of the total lease revenue, water management costs doubled in this period (van Bavel 1993). As a result, and combined with the negative effects on the local economy, the existing institutional option of abandoning a parcel with diking duties now proved problematic as the growing incidence of floods in a feedback loop reduced the profitability of farming and resulted in a growing number of vacant parcels, which further increased pressure on the remaining tax base.

This situation had a negative effect on the incidence of floods, which further increased in frequency and intensity in the $1570 \mathrm{~s}$ and remained at a high level across the whole of the 17th century. There were floods in 1565, 1570-1571, 1587, and 1595, and many of these were serious. The flood of 1570 , for instance, not only drowned large tracts of land, but also destroyed watermills, dikes, quays, and bridges (Gottschalk 1975). The series of floods continued in the 17 th century, with no fewer than seven floods in the opening decades, followed by a catastrophic flood in January and February 1624. Following this event, there were continuing floods in the following decades. Also, the land increasingly suffered from the increasing nuisance of seeping that now became almost semipermanent and was turned over to very extensive use (Brusse 1999), to be characterized here as a form of land loss. In 1650 tax records noted that many lower-lying lands spent long periods under water in the winter (Curtis 2014a). All this suggests that the organization of water management was not fit for a context of high inequality at both the owner and the user level, and the effects were detrimental to resilience as a result of a negative feedback loop between these elements. Despite the evident severity of the floods, however, the rules of water management were not adapted. The decision-making power of large landlords and local communities dominated by large-scale tenant farmers and middling landowners, who had most interest in the existing arrangements, and whose position was buttressed by their economic dominance, could not be broken by either central authorities or small landowners and small tenants, with these last groups being hit hardest by the severe floods.

\section{Northern Groningen, 1500-1800}

Northern Groningen, as the northernmost point of the Netherlands and comprising the two historic regions of Hunsingo and Fivelgo, is a coastal region lining the Wadden Sea (Fig. 4). Problems with storm surges were identified as far back as the early Middle Ages, when communities raised their houses or even whole villages on artificial mounds (terpen). As more land became reclaimed closer to the sea for habitation and agriculture, there was even greater need for protection via networks of dikes, ditches, and mills. This area then remained at risk of inundation through floods caused by storm surges. 
1500-1635: Low inequality of landownership and relative equality in land use, unchanged institutions, frequent low severity flooding

Prior to the 17 th century, limited sources we have at our disposal suggest a relatively equitable society of free peasant farmers who owned their own land, with weak traditions of feudalism and absentee overlordship (Knottnerus 2013). Urban landlords had yet to invest to a large degree in rural landownership in Northern Groningen. Jaartaxen (simpler precursors for the later verpondingen) for individual scattered parishes in the second half of the 15th century and in the 16th century also suggest high equality in distribution of land use with low Gini coefficients around 0.5 (Curtis 2016a). In 1630, the date of the earliest fiscal land register for whole region of Groningen (verponding), the Gini coefficient for both regions of Hunsingo and Fivelgo was still only around 0.59 (Curtis 2016a).

Medieval water management in Groningen was largely based around a localized organization of water boards, which continued into the 16th and 17th centuries (Ligtendag 1995). These water boards employed a Kabeldeichung system, where each peasant farmer had individual responsibility for making the necessary flood defenses according to their landholding.

In some parts of Groningen, such as in the east in the Oldambt and Reiderland, water management was badly compromised by tribal colonist conflict (Knottnerus 2013). After the Cosmas- and Damianus Flood, which created the Dollard Sea in 1509, there were at least 11 separate flood events from 1554-1597 in the Oldambt, the most serious being the All Saints Flood of 1570, which left arable fields submerged for months afterward (Vermue 2012). However, it appears that the Kabeldeichung system was much more effective in Northern Groningen (Knottnerus 2013). For example, while in other parts of the North Sea area, the flood of 1570 created hundreds of casualties (Homeier 1970, Rheinheimer 2003), there is little evidence that substantial deaths occurred in the regions of Hunsingo and Fivelgo (Rienks and Rienst-Wallinga 1970). In 1634, the Burchardi Flood created significant casualties in the neighboring northern areas of North Frisia and Dithmarschen, and yet from the few burial records we have for villages in Northern Groningen (Westeremden and Garnswerd), no mortality effect can be discerned at all, the only exception being the Oldambt village of Midwolda, and this was attributed to a localized outbreak of smallpox instead (burials database used in Curtis 2016b). Overall then, although Gottschalk noted 32 flood events in the period 1500-1634 in Groningen (1975), most of these were localized and not particularly damaging, and the most severe ones, such as that of 1509, afflicted other areas outside Northern Groningen.

\section{5-1725: Rising inequality in landownership and rising inequality in land use, unchanged institutions, infrequent high severity flooding}

Changes occurred in the distribution of property during the 17 th century. In large parts of the province, land was increasingly shifted out of the hands of local peasant farmers and consolidated more with elite landowners, often urban institutions and wealthy burghers from Groningen city (Hoppenbrouwers 1991, Curtis 2016a). In nearby Oldambt, only a third of the land was left in the hands of rural inhabitants by 1721 (Curtis 2014b), and in other parts of inland clay-soil areas it was as low as a quarter (Paping
1995). In the regions of Hunsingo and Fivelgo, the Gini coefficient for user-level property distribution moved from 0.59 (in both areas) in 1630 to 0.68 and 0.71 , respectively, in 1721 (Curtis 2016a). These increases in Gini coefficients must also be taken as an absolute minimum given that the fiscal sources fail to record the increasing proportions of landless.

Although from the 16th and particularly 17 th century onward the city of Groningen began to accumulate land and bring rural areas into its jurisdictional sphere, it did little to invest in the protection of this land from water, with the exception of urban-financed dikes draining the fenlands and connecting canals to Westfalen ('t Hart 1998). The city remained exempt from dike maintenance costs until the second half of the 17 th century, and even then, only partial contributions were made. In 1686 during the St. Martin's Flood, Groningen did give partial assistance (Ufkes 1984), though during the Christmas Floods of 1717, the city once again retreated from an active role (Sundberg 2015). Across the 17 th century then, we see increasing consolidation of property and jurisdiction by absentee elites, yet very minimal investments or contribution from the same parties in water management. Urban landowners continued to maintain the principles of the medieval Kabeldeichung system, urging their tenants instead to make necessary capital and labor contributions. Even after the disastrous Christmas Flood of 1717, the provincial committee noted in a resolution that it was the responsibility of farmers allocated to a specific portion of the dike to make repairs (Sundberg 2015), yet when agricultural prices dropped post-1650, it was impossible for tenants to make those investments, particularly given that prior abandonment of smallholdings left remaining farmers responsible for 10 or more parts of a dike. The clear threat and direct experience of floods in Northern Groningen failed to stimulate any kind of institutional adaptation.

This flooding situation in Hunsingo and Fivelingo therefore changed during the second half of the 17th century, with the terrible St. Martin's Flood of 1686, killing approximately 1900 people (1600 in Groningen province). The village of Termunten in 1686 recorded 223 dead during the St. Martin's Flood ( 53 noted explicitly as bodies fished out of the water), when the usual annual burial rate was around 25 (burials database used in Curtis 2016b). If we estimate a death rate of around $4 \%$ of the population in normal times (for 17th-century Groningen; Schroor 2014), this may have been around $40 \%$ of the population. Moreover, out of more than 450 localities in a recently compiled 17 th-century burials database, with mortality data for more than 22,000 individual years, the relative increase in burials in Termunten in 1686 was third out of c. 22,000 , comparable to the most severe epidemics (burials database used in van Besouw and Curtis 2018). Similarly, the nearby village of Woldendorp in 1686 was ranked 101 out of c.22,000. Following this, the Christmas Flood of 1717 killed around 2300 people and 35,000 animals in Groningen province, leaving dikes not only broken but completely submerged (Sundberg 2015). Many of those who died were poor laborers, while wealthier farmers tended to survive (Paping 2017, Soens 2018). Essentially all of Northern Groningen was affected in 1717 (as seen from shaded area of the map in Fig. 5). The scale of destruction then completely overshadowed any minor localized floods that came before or after this period. 
Fig. 5. Detail from Geographische Vorstellung der jämerlichen Wasser-Flutt in Nieder-Teutschland, edit von Joh. Bapt. Homann, Der Röm. Keis. Mai. Georg. in Nürnberg, 1717, Groninger Archieven, Groningen

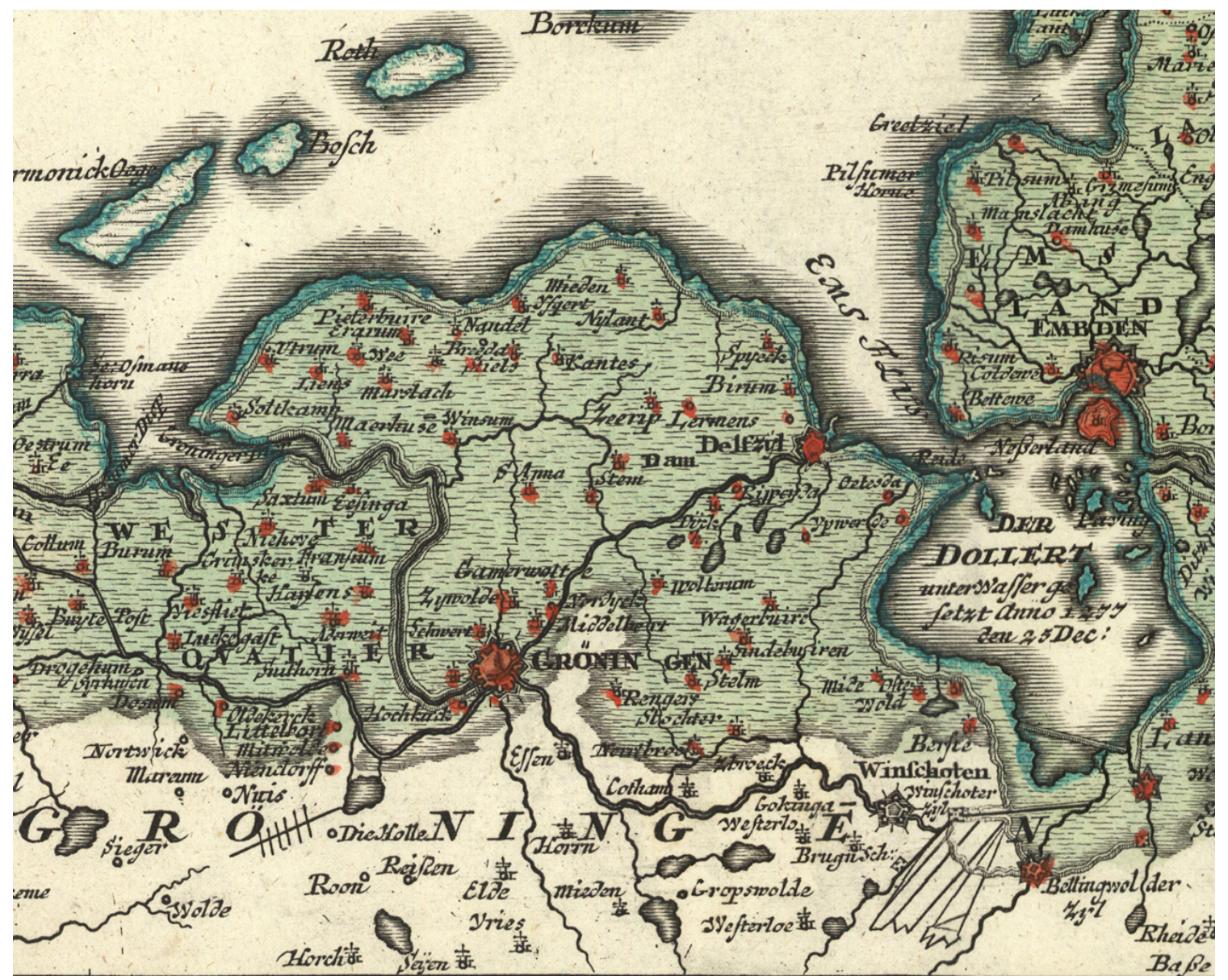

Given the obvious negative outcomes, the question then is why the water management system failed to be adapted to suit the changes in redistributive context? Why continue with the principles of the medieval Kabeldeichung system, more suited to a flat-hierarchy peasant society, when it was clear that most elements of this peasant society were being eroded during the $17 \mathrm{th}$ century? The alternative solution should have been investment from the parties acquiring the property in the 17 th century, that is the wealthy urban burghers and powerful institutions from the city of Groningen itself who, instead of directly offering labor assistance, should have provided the capital for waged labor assistance. These wealthy urban groups, however, were reluctant to invest in spite of their property acquisitions, and this can be explained by the historic tensions between the city and the socalled provincial administration, or Ommelanden (Sundberg 2015), and exacerbated further by rural regions asserting their autonomy (Curtis 2014b). Both the city and the provincial administrations selectively invoked past precedents and customs as a way of avoiding the onerous weight of the financial burden that water management now bore, and when each saw the other as the responsible party, they waited for each other to make the first or more decisive commitment (Sundberg 2015). Even in times of necessity then, as water management structures began to clearly crumble (see the report of 1687 on the noted precarious nature of the dikes: Groninger Archieven, Ommelander Archiven 1558-1862, no. 1084, fos 388-90), adaptation did not merely mirror redistributive changes, and nor was adaptation an inevitable consequence of increased flooding, but instead was dependent on socio-political context.

Post-1725: Continued high inequality in landownership and rising inequality in land use, changing institutions, infrequent low severity flooding

After the Christmas Flood of 1717, land changed hands frequently; between 1717 and 1721 on province-owned lands, around $30-35 \%$ of holdings changed hands between tenants, whereas in normal times it was annually less than $2 \%$ in many parts of the early modern Netherlands (van Bavel 2004). Land consolidation at the user level was initially limited, however, because land value and prices of agricultural products were so low that no incentives existed to do so (Knottnerus 2004). Unrelated to the floods, only after 1750 do we see the return of increased inequality in land use, this time to an excessive degree as we witness the emergence of the classic polarized society of gentleman farmers with large landholdings and agricultural laborers who were almost landless in Groningen (Curtis 2014b), 
Fig. 6. Analytical framework that links the exogenous hazard of water surges to institutions embedded in their socio-political context (with levels of equality as a main characteristic) and outcomes (flood disaster or not), with a suggested feedback loop leading back to institutions (adaptation or rigidity).

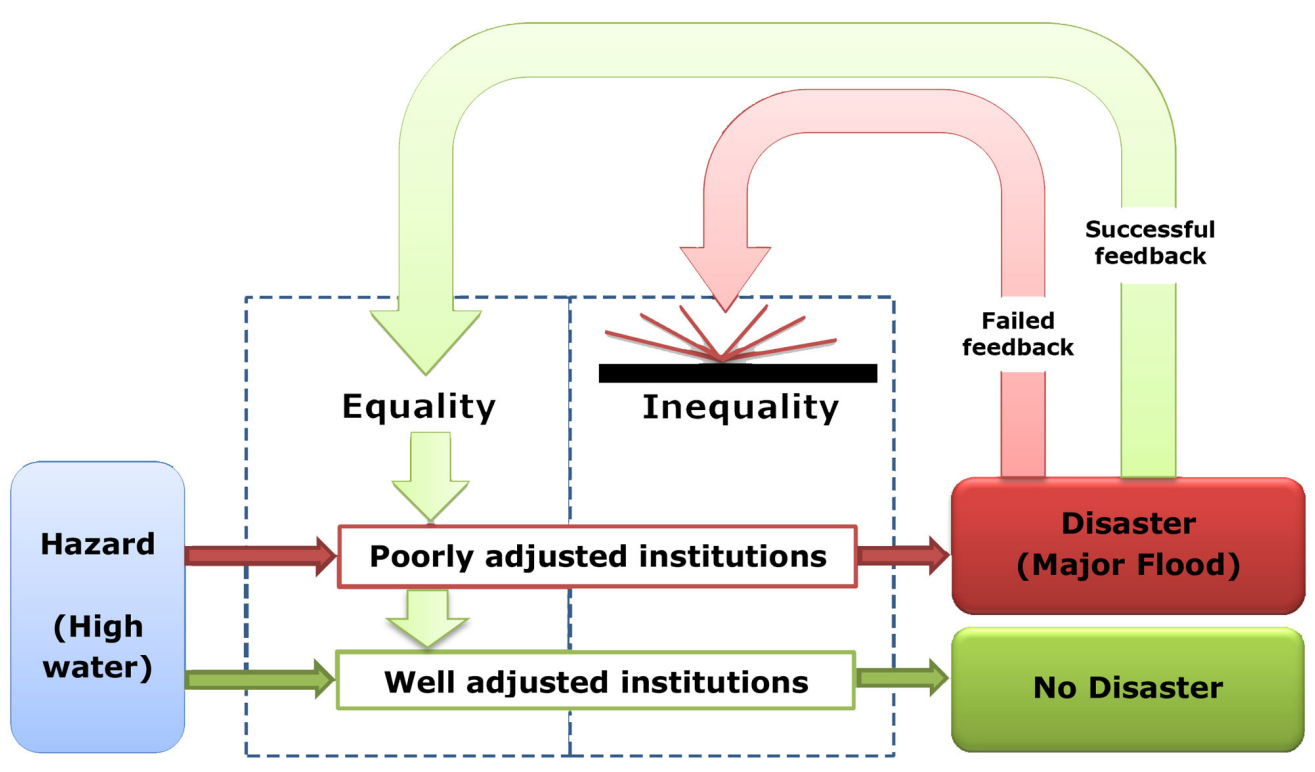

where in the Oldambt, for example, Gini coefficients for property distribution were in excess of 0.85 by 1821 , and were likely similar in Hunsingo and Fivelgo, given the exact same farmer-laborer structure had emerged in Northern Groningen in the second half of the 18th century (Botke 2002).

Whereas in the previous period (the 17 th and early 18 th centuries), water management institutions remained rather rigid and unsuited to the changing property distribution context, a key difference in the later period after the Christmas Floods of 1717 was that changing tenurial conditions allowed tenant farmers to more effectively involve themselves in the water management institutions. Especially post-1750, tenant farmers exploited the twin situation of a favorable system of beklemrecht (where land rents were fixed over the long term) and rising agricultural prices to strengthen their position vis-à-vis the real owners of the land, so much so that many of these large farmers eventually became outright owners (Knottnerus 2004). As a result, investment in all the necessary water management structures became clearer and farmers had a greater propensity to do so. Accordingly, although the lack of adaptation in the previous period, in spite of severe flood hazards, was connected to a stand-off between two responsible parties of city and province, in a later period this vacuum was circumvented by the emergence of a third party, the rural tenant farmers themselves, who were now stronger than before.

It is no coincidence then that the adaptation of the institutional framework surrounding water management to suit the changes in the context for inequitable property distribution also occurred along a similar chronology to the disappearance of severe flooding outcomes in Groningen. The only exception to this was the case of localized breaks in dikes around the city of Groningen in 1825 , the direct consequences being rather minor for mortality and losses of production factors, but having indirect effects on mortality as the rotting plants and animals in the morasses led to an outbreak of malaria, killing $10 \%$ of the population (Baron 2006).

\section{CONCLUSION}

In this paper, we have analyzed the interaction between economic inequality and institutional adaptation in the face of flood hazards. In doing so, we have used the frequency and severity of floods in three flood-prone areas as an indicator of breakdown in resilience. It is important to note that we first establish that storm surges and high water tables are an exogenous variable but the incidence of major floods, as an indicator of the level of resilience of the region in question, is to a large extent caused by societal qualities and the organization of water management itself: more specifically by the degree to which the institutional organization could be adapted to changing circumstances to cope with these storm surges and high water tables.

Our long-run historical and comparative analysis shows first that if institutions do not adapt to meet the changes in the distribution context, severe floods are more likely to occur (Fig. 6). Economic inequality per se does not need to affect resilience negatively, as long as the institutional framework adapts accordingly. Some very unequal societies thus proved able to cope with floods (Groningen after 1720, and Flanders in the 16th century to a more limited extent). What mattered, however, was the interplay between institutions and the social context. When institutions developed within an equal distribution of material resources, and inequality started to rise, this led to more frequent and heavier floods and recurrent problems with water in all of the cases. This was the direct effect of inequality on the functioning of these institutions, 
but it may also be argued that the transfer of land to larger landholders, who lived further away, and the related monetization of water management, created a distance between the resource users and the infrastructure, leading to a deterioration of management (for this line of reasoning elsewhere, see Anderies et al. 2016). Exact mechanisms are hard to investigate for these historical cases, to which contemporary observations and experiments would be better suited, but history enables us to observe the outcomes at the macro level over a longer period. These outcomes for resilience as a result of rising inequality were negative, which in a feedback loop, as a result of the destruction and distress the major floods caused, led to a further rise of inequality, as again observed during phases in all three cases.

It is interesting to notice that a decrease in inequality, unparalleled by changes in the institutional framework, could produce similar problems (as demonstrated by Coastal Flanders after 1350). When institutions in this second stage are adapted and become fit for a situation of high inequality, however, as seen in Groningen after 1720, they can sustain resilience in the longer run, as evidenced by the declining numbers of floods and the extension of the land surface won on the water. At the same time, these new institutions also consolidate the high levels of inequality. Ultimately, both equitable and inequitable societies can demonstrate resilience in the face of strong hazards such as floods, but the institutional arrangements used to deal with the hazard must be suited to the distributive context present.

The second main conclusion of our historical and comparative analysis concerns the inevitability of institutional adaptation. Our analysis shows that even after decreased resilience, in cases where institutions did not adapt to changing circumstances, and where this led to a growing incidence of disastrous floods, it was not at all inevitable that institutions adapted in response to these pressures (for a comparative study, see Rohland 2018). For example, increased flooding in 16th-century Guelders and 17thcentury Groningen failed to provoke any kind of necessary institutional changes. Instead when powerful actors and interest groups have excessive control over institutions, they may persist even if they actually weaken a society's coping capacity. These cases, where the incentive of restricted groups outweighs the needs of the wider community, are most likely to occur when economic resources are more unequally divided across society, and therefore inequality itself becomes a powerful obstacle, or counterweight, against inevitable posthazard adaptation

These conclusions are relevant today, although they cannot fully and directly translate to present situations. First, water management was organized mainly at a local and regional level, whereas nowadays the role of states and central bureaucracies are stronger. Second, as a result of the relatively small geographical scale of the units used here, differences in value orientation (as discussed by Jones et al. 2016) do not play a role, whereas comparing larger areas across the globe may differ and affect outcomes. Notwithstanding these limitations, the results of the paper offer empirical evidence of the interplay between economic inequality and institutional adaptation. They show that neither high inequality nor types of institutional settings work inevitably or intrinsically to the detriment of resilience, but changes in one without the other instead proved to be much more harmful. This may help explain why research has failed to draw a consistent connection between inequality and diminishing resilience. This connection does exist, as this paper shows, but not in a unilinear way and only in interaction with a process of institutional adaptation or lack thereof. ${ }^{[1]}$ Thanks to Remi van Schaïk for this reference taken from his
unpublished "calamity calendar."

Responses to this article can be read online at: http://www.ecologyandsociety.org/issues/responses. php/10491

\section{Acknowledgments:}

For their suggestions on earlier versions of this paper we thank Marco Janssen (Arizona), Marten Scheffer (Wageningen), Gerrit Jasper Schenk (Darmstadt), and Eric Vanhaute (Ghent) and the participants of the "Coordinating for Life" workshop at Utrecht University and the WINIR Conference in Boston, 2016. We also thank Annelies Tukker for her help with the references. We gratefully acknowledge the support of the European Research Council (ERC) for the project "Coordinating for Life" (Advanced Grant no. 339647); the Netherlands Organisation for Scientific Research (NWO) for the project Why Do Some Epidemics Lead to Hatred? (VENI Grant no. 275-53-014); and the Flemish Science Foundation FWO for the project "Shock cities? Food prices and access to food in Flemish cities in an age of crises (1280-1370)."

\section{LITERATURE CITED}

Adger, W. N. 2003. Social capital, collective action, and adaptation to climate change. Economic Geography 79 (4):387-404.

Alfani, G., and F. Ammannati. 2017. Long-term trends in economic inequality: the case of the Florentine state, c. 13001800. Economic History Review 70(4):1072-1102. http://dx.doi. org/10.1111/ehr.12471

Alfani, G., and C. Ó Gráda, editors. 2017. Famine in European history. Cambridge University Press, Cambridge, UK. http://dx. doi.org/10.1017/9781316841235

Anderies, J. M., M. A. Janssen, and E. Schlager. 2016. Institutions and the performance of coupled infrastructure systems. International Journal of the Commons 10(2):495-516. http://dx. doi.org/10.18352/ijc.651

Augustyn, B. 1992. Zeespiegelrijzing, transgressiefasen en stormvloeden in maritiem Vlaanderen tot het einde van de XVIde eeuw: een landschappelijke, ecologische en klimatologische studie in historisch perspektief. Algemeen Rijksarchief, Brussels, Belgium.

Barnes, M. L., Ö. Bodin, A. M. Guerrero, R. J. McAllister, S. M. Alexander, and G. Robins. 2017. The social structural foundations of adaptation and transformation in social-ecological systems. Ecology and Society 22(4):16. https://doi.org/10.5751/ES-09769-220416 
Baron, W. 2006. 'Het belang en de welvaart van alle ingezetenen': gezondheidszorg in de stad Groningen 1800-1870. Dissertation. University of Groningen, Groningen, The Netherlands.

Béné, C., R. M. Al-Hassan, O. Amarasinghe, P. Fong, J. Ocran, E. Onumah, R. Ratuniata, T. Van Tuyen, J. A. McGregor, and D. J. Mills. 2016. Is resilience socially constructed? Empirical evidence from Fiji, Ghana, Sri Lanka, and Vietnam. Global Environmental Change 38:153-170. https://doi.org/10.1016/j. gloenvcha.2016.03.005

Blaikie, P., T. Cannon, I. Davis, and B. Wisner. 2004. At risk. Natural hazards, people's vulnerability, and disasters. Second editiion. Routledge, New York, New York, USA.

Bodin, Ö. 2017. Collaborative environmental governance: achieving collective action in social-ecological systems. Science 357(6352):eaan1114. http://dx.doi.org/10.1126/science.aan1114

Botke, I. 2002. Boer en heer: de 'groninger boer' 1760-1960. Van Gorcum, Assen, The Netherlands.

Brusse, P. 1999. Overleven door ondernemen. De agrarische geschiedenis van de Over-Betuwe 1650-1850. Landbouwuniversiteit, Afdeling Agrarische Geschiedenis, Wageningen, The Netherlands.

Brusse, P. 2018. Property, power and participation in local administration in the Dutch delta in the early modern period. Continuity and Change 33(1):59-86. http://dx.doi.org/10.1017/ $\underline{\mathrm{S} 0268416018000048}$

Buisman, J. 1995-2015. Duizend jaar weer, wind en water in de Lage Landen. Volumes 1-6. Van Wijnen, Franeker, The Netherlands.

Carpenter, S. R., and W. A. Brock. 2008. Adaptive capacity and traps. Ecology and Society 13(2):40. http://dx.doi.org/10.5751/ ES-02716-130240

Carter, M. R., P. D. Little, T. Mogues, and W. Negatu. 2007. Poverty traps and natural disasters in Ethiopia and Honduras. World Development 35(5):835-856. http://dx.doi.org/10.1016/j. worlddev.2006.09.010

Castillo, G. E., and D. Hillier. 2013. No accident: resilience and the inequality of risk. Oxfam Briefing Paper 172.

Cinner, J. E. 2011. Social-ecological traps in reef fisheries. Global Environmental Change 21(3):835-839. http://dx.doi.org/10.1016/ j.gloenvcha.2011.04.012

Crona, B., and Ö. Bodin. 2010. Power asymmetries in small-scale fisheries: a barrier to governance transformability? Ecology and Society 15(4):32. https://doi.org/10.5751/ES-03710-150432

Cumming, G. S., D. H. M. Cumming, and C. L. Redman. 2006. Scale mismatches in social-ecological systems: causes, consequences, and solutions. Ecology and Society 11(1):14. http:// dx.doi.org/10.5751/ES-01569-110114

Curtis, D. R. 2014a. Coping with crisis: the resilience and vulnerability of pre-industrial settlements. Ashgate, Farnham, UK.

Curtis, D. R. 2014b. The impact of land accumulation and consolidation on population trends in the pre-industrial period: two contrasting cases in the Low Countries. Historical Research 87(236):194-228. http://dx.doi.org/10.1111/1468-2281.12050
Curtis, D. R. 2016a. Danger and displacement in the Dollard: the 1509 flooding of the Dollard Sea (Groningen) and its impact on long-term inequality in the distribution of property. Environment and History 22(1):103-135. http://dx.doi.org/10.3197/096734016$\underline{\mathrm{X} 14497391602288}$

Curtis, D. R. 2016b. Was plague an exclusively urban phenomenon? Plague mortality in the seventeenth-century Low Countries. Journal of Interdisciplinary History 47(2):139-170. http://dx.doi.org/10.1162/JINH a 00975

Curtis, D. R., B. van Bavel, and T. Soens. 2016. History and the social sciences: shock therapy with medieval economic history as patient. Social Science History 40(4):751-774. http://dx.doi. org/10.1017/ssh.2016.30

Dangendorf, S., F. M. Calafat, A. Arns, T. Wahl, I. D. Haigh, and J. Jensen. 2014. Mean sea level variability in the North Sea: processes and implications. Journal of Geophysical Research: Oceans 119(10):6820-6841. http://dx.doi.org/10.1002/2014JC009901

Degroot, D. 2018. The frigid Golden Age: climate change, the Little Ice Age and the Dutch Republic, 1560-1720. Cambridge University Press, Cambridge, UK. http://dx.doi.org/10.1017/9781108297639

de Kraker, A. 1997. Landschap uit balans: de invloed van de natuur, de economie en de politiek op de ontwikkeling van het landschap in de Vier Ambachten en het Land van Saeftinghe tussen 1488 en 1609. Uitgeverij Matrijs, Utrecht, The Netherlands.

de Kraker, A. 2013. Storminess in the Low Countries, 1350-1725. Environment and History 19(2):149-171. http://dx.doi. org/10.3197/096734013X13642082568570

de Kraker, A. 2015. Flooding in river mouths: human caused or natural events? Five centuries of flooding events in the SW Netherlands, 1500-2000. Hydrology and Earth System Sciences 19 (6):2673-2684. http://dx.doi.org/10.5194/hess-19-2673-2015

Dekker, C., and R. Baetens. 2010. Geld in het water: Antwerps en Mechels kapitaal in Zuid-Beveland na de stormvloeden in de 16de eeuw. Verloren, Hilversum, The Netherlands.

Dombrecht, K., and W. Ryckbosch. 2017. Wealth inequality in a time of transition: coastal Flanders in the sixteenth century. Tijdschrift voor Sociale en Economische Geschiedenis/Low Countries Journal of Social and Economic History 14(2):63-84. http://dx.doi.org/10.18352/tseg.917

Endfield, G. H. 2012. The resilience and adaptive capacity of social-environmental systems in Colonial Mexico. Proceedings of the National Academy of Sciences USA 109(10):3676-3681. http:// dx.doi.org/10.1073/pnas. 1114831109

Enfors, E. 2013. Social-ecological traps and transformations in dryland agro-ecosystems: using water system innovations to change the trajectory of development. Global Environmental Change 23(1):51-60. http://dx.doi.org/10.1016/j.gloenvcha.2012.10.007

Engle, N. L. 2011. Adaptive capacity and its assessment. Global Environmental Change 21(2):647-656. http://dx.doi.org/10.1016/ j.gloenvcha.2011.01.019

Fabinyi, M., L. Evans, and S. J. Foale. 2014. Social-ecological systems, social diversity, and power: insights from anthropology and political ecology. Ecology and Society 19(4):28. http://dx.doi. org/10.5751/ES-07029-190428 
Folke, C., S. R. Carpenter, B. Walker, M. Scheffer, T. Chapin, and J. Rockström. 2010. Resilience thinking: integrating resilience, adaptability and transformability. Ecology and Society 15(4):20. http://dx.doi.org/10.5751/ES-03610-150420

Folke, C., T. Hahn, P. Olsson, and J. Norberg. 2005. Adaptive governance of social-ecological systems. Annual Review of Environment and Resources 30:441-473. http://dx.doi.org/10.1146/ annurev.energy.30.050504.144511

Galloway, J. A. 2009. Storm flooding, coastal defense and land use around the Thames estuary and tidal river c.1250-1450. Journal of Medieval History 35(2):171-188. http://dx.doi. org/10.1016/j.jmedhist.2008.12.001

Gottschalk, M. 1971. Stormvloeden en rivieroverstromingen in Nederland. Volume I. Van Gorcum, Assen, The Netherlands.

Gottschalk, M. 1975. Stormvloeden en rivieroverstromingen in Nederland. Volume II. Van Gorcum, Assen, The Netherlands.

Gottschalk, M. 1977. Stormvloeden en rivieroverstromingen in Nederland. Volume III. Van Gorcum, Assen, The Netherlands.

Hoddinott, J. 2006. Shocks and their consequences across and within households in rural Zimbabwe. Journal of Development Studies 42(2):301-321. http://dx.doi.org/10.1080/00220380500405501

Homeier, H. 1970. Die Allerheiligenflut von 1570 in Ostfriesland. Pages 62-78 in K. de Vries and J. P. Winsemius, editors. De Allerheiligenvloed van 1570. Miedema Pers, Leeuwarden, The Netherlands.

Hoppenbrouwers, P. 1991. Grondgebruik en agrarische bedrijfsstructuur in het Oldambt na de vroegste inpolderingen (ca. 1630-ca. 1720). Pages 73-95 in J. Elerie and P. Hoppenbrouwers, editors. Het Oldambt, deel 2. Nieuw visies op geschiedenis en actuele problemen. Nederlands Agronomisch Historisch Instituut, Groningen, The Netherlands.

Intergovernmental Panel on Climate Change (IPCC). 2014. Summary for policymakers. In C. B. Field, V. R. Barros, D. J. Dokken, K. J. Mach, M. D. Mastrandrea, T. E. Bilir, M. Chatterjee, K. L. Ebi, Y. O. Estrada, R. C. Genova, B. Girma, E. S. Kissel, A. N. Levy, S. MacCracken, P. R. Mastrandrea, and L. L. White, editors. Climate change 2014: impacts, adaptation, and vulnerability. Part A: global and sectoral aspects. Contribution of Working Group II to the Fifth Assessment Report of the Intergovernmental Panel on Climate Change. Cambridge University Press, Cambridge, UK.

Jakubowski-Tiessen, M. 1992. Sturmflut 1717: die Bewältigung einer Naturkatastrophe in der Frühen Neuzeit. R. Oldenbourg Verlag, Munich, Germany. http://dx.doi.org/10.1515/9783486828023

Jones, N. A., S. Shaw, H. Ross, K. Witt, and B. Pinner. 2016. The study of human values in understanding and managing socialecological systems. Ecology and Society 21(1):15. http://dx.doi. org/10.5751/ES-07977-210115

Kahn, M. E. 2005. The death toll from natural disasters: the role of income, geography, and institutions. Review of Economics and Statistics 87(2):271-284. http://dx.doi.org/10.1162/0034653053970339

Kaufmann, M., J. Lewandowski, A. Choryński, and M. Wiering. 2016. Shock events and flood risk management: a media analysis of the institutional long-term effects of flood events in the Netherlands and Poland. Ecology and Society 21(4):51. http://dx. doi.org/10.5751/ES-08764-210451

Klein, R. J. T., G. F. Midgley, B. L. Preston, M. Alam, F. G. H. Berkhout, K. Dow, and M. R. Shaw. 2014. Adaptation opportunities, constraints, and limits. Chapter 16 in C. B. Field, V. R. Barros, D. J. Dokken, K. J. Mach, M. D. Mastrandrea, T. E. Bilir, M. Chatterjee, K. L. Ebi, Y. O. Estrada, R. C. Genova, B. Girma, E. S. Kissel, A. N. Levy, S. MacCracken, P. R. Mastrandrea, and L. L. White, editors. Climate change 2014: impacts, adaptation, and vulnerability. Part A: global and sectoral aspects. Contribution of Working Group II to the Fifth Assessment Report of the Intergovernmental Panel on Climate Change. Cambridge University Press, Cambridge, UK.

Knottnerus, O. 2004. Yeoman and farmers in the Wadden Sea coastal marshes, c.1500-1900. Pages 149-186 in B. J. P. van Bavel, and P. Hoppenbrouwers, editors. Landholding and land transfer in the North Sea area (late Middle Ages-19 th century). Brepols, Turnhout, Belgium.

Knottnerus, O. 2013. Reclamations and submerged lands in the Ems River estuary (900-1500). Pages 241-266 in E. Thoen, G. J. Borger, A. M. J. de Kraker, T. Soens, D. Tys, L. Vervaet, and H. J. T. Weerts, editors. Landscapes or seascapes? The history of the coastal environment in the North Sea area reconsidered. Brepols, Turnhout, Belgium.

Kuys, J., L. de Leeuw, V. Paquay, and R. van Schaïk, editors. 1983. De Tielse Kroniek: een geschiedenis van de Lage Landen van de Volksverhuizingen tot het midden van de vijftiende eeuw, met een vervolg over de jaren 1552-1566. Verloren, Hilversum, The Netherlands.

Ligtendag, W. 1995. De Wolden en het water: de landschaps- en waterstaatsontwikkeling in het lage land ten oosten van de stad Groningen vanaf de volle middeleeuwen tot ca. 1870. Van Dijk \& Foorthuis, Groningen, The Netherlands.

Moorman van Kappen, O., J. Korf, and, O. W. A. Baron van Verschuer. 1977. Tieler-en Bommelerwaarden 1327-1977. Grepen uit de geschiedenis van 650 jaar waterstaatszorg in Tielerwaard en Bommelerwaard. Polderdistrict Tielerwaard en Polderdistrict Bommelerwaard: Tiel/Zaltbommel, The Netherlands.

Nee, V., and P. Ingram. 1998. Embeddedness and beyond: institutions, exchange and social structure. Pages 19-45 in M. C. Brinton and V. Nee, editors. The new institutionalism in sociology. Stanford University Press, Palo Alto, California, USA.

Nijenhuis, H. D. 1992. Hulsterambacht. Penningkohieren 1570-1580. Afdeling Zeeland van de Nederlandse Genealogische Vereniging, Hulst, The Netherlands.

Ogilvie, S. 2007. 'Whatever is, is right?' Economic institutions in pre-industrial Europe. Economic History Review 60(4):649-684. http://dx.doi.org/10.1111/j.1468-0289.2007.00408.x

Paping, R. 1995. Voor een handvol stuivers: de levensstandaard van boeren, arbeiders en middenstanders op de Groninger klei, 1770-1860. Nederlands Agronomisch Historisch Instituut, Groningen, The Netherlands.

Paping, R. 2017. De kerstvloed van 1717 in Vliedorp en Wierhuizen. Stad en Lande 26(4):10-13. 
Pelling, M. 2003. The vulnerability of cities: natural disasters and social resilience. Earthscan, London, UK.

Rheinheimer, M. 2003. 'Mythos Sturmflut.' Der Kamp gegen das Meer und die Suche nach Identität. Demokratische Geschichte 15:9-58.

Rienks, K. A., and D. Rienst-Wallinga. 1970. De Allerheljenfloed fan 1570 yn Grinslân. Pages 41-61 in K. de Vries and J. P. Winsemius, editors. De Allerheiligenvloed van 1570. Miedema Pers, Leeuwarden, The Netherlands.

Rippon, S. 2000. The transformation of coastal wetlands: exploitation and management of marshland landscapes in North West Europe during the Roman and medieval periods. Oxford University Press, Oxford, UK.

Rohland, E. 2018. Adapting to hurricanes: a historical perspective on New Orleans from its foundation to Hurricane Katrina, 1718-2005. WIREs Climate Change 9(1):e488. http://dx.doi. org $/ 10.1002 /$ wcc. 488

Schroor, M. 2014. Rurale metropool. Bevolking, migratie en financiën van de stad Groningen ten tijde van de Republiek (1595-1795). Nederlands Agronomisch Historisch Instituut, Groningen, The Netherlands.

Smith, T. 2014. Warping and parliamentary enclosure: the example of north-west Lindsey, Lincolnshire. Agricultural History Review 62(1):83-97.

Soens, T. 2009. De spade in de dijk? Waterbeheer en rurale samenleving in de Vlaamse kustvlakte (1280-1580). Academia Press, Ghent, Belgium. http://dx.doi.org/10.26530/OAPEN 611030

Soens, T. 2011. Floods and money: funding drainage and flood control in Coastal Flanders from the thirteenth to the sixteenth centuries. Continuity and Change 26(3):333-365. http://dx.doi. org/10.1017/S0268416011000221

Soens, T. 2013a. The social distribution of land and flood risk along the North Sea Coast: Flanders, Holland and Romney Marsh compared (c. 1200-1750). Pages 147-179 in B. van Bavel and E. Thoen, editors. Rural societies and environments at risk: ecology, property rights and social organisation in fragile areas (Middle Ages-Twentieth century). Brepols, Turnhout, Belgium. http://dx.doi.org/10.1484/M.RURHE-EB.4.00111

Soens, T. 2013b. Flood security in the medieval and early modern North Sea area: a question of entitlement? Environment and History 19:209-232. http://dx.doi.org/10.3197/096734013X1364$\underline{2082568651}$

Soens, T. 2018. Resilient societies, vulnerable people: coping with North Sea floods before 1800. Past \& Present 241:143-177. http:// dx.doi.org/10.1093/pastj/gty018

Soens, T., and E. Thoen. 2008. The origins of leasehold in the former county of Flanders. Pages 31-55 in B. van Bavel, and P. R. Schofield, editors. The development of leasehold in Northwestern Europe, c. 1200-1600. Brepols, Turnhout, Belgium. http://dx.doi. org/10.1484/M.CORN-EB.3.313

Soens, T., D. Tys, and E. Thoen. 2014. Landscape transformation and social change in the North Sea polders, the example of Flanders (1000-1800 AD). Siedlungsforschung. ArchäologieGeschichte-Geographie 31:133-160.
Sundberg, A. 2015. Floods, worms and cattle plague: natureinduced disaster at the closing of the Dutch Golden Age, 1672-1764. Dissertation. University of Kansas, Lawrence, Kansas, USA.

Suursaar, Ü, J. Jaagus, and H. Tõnisson. 2015. How to quantify long-term changes in coastal sea storminess? Estuarine, Coastal and Shelf Science 156:31-41. http://dx.doi.org/10.1016/j. ecss.2014.08.001

't Hart, M. 1998. Rulers and repertoires: the revolt of a farmers' republic in the early modern Netherlands. Pages 197-212 in M. Hanagan, L. Page Morch, and W. te Brake, editors. Challenging authority: the historical study of contentious politics. University of Minnesota Press, Minneapolis, Minnesota, USA.

TeBrake, W. 1993. A plague of insurrection: popular politics and peasant revolt in Flanders, 1323-1328. University of Pennsylvania Press, Philadelphia, Pennsylvania, USA.

Thoen, E., and T. Soens. 2015. The family or the farm: a Sophie's Choice? The late medieval crisis in Flanders. Pages 196-224 in J. Drendel, editor. Crisis in the later Middle Ages: beyond the PostanDuby paradigm. Brepols, Turnhout, Belgium. http://dx.doi. org/10.1484/M.TMC.5.103788

Tierney, K. J. 2007. From the margins to the mainstream? Disaster research at the crossroads. Annual Review of Sociology 33 (1):503-525. http://dx.doi.org/10.1146/annurev.soc.33.040406.131743

Tys, D. 2013. The medieval embankment of coastal Flanders in context. Pages 199-239 in E. Thoen, G. J. Borger, A. M. J. de Kraker, T. Soens, D. Tys, L. Vervaet, and H. J. T. Weerts, editors. Landscapes or seascapes? The history of the coastal environment in the North Sea area reconsidered. Brepols, Turnhout, Belgium. http://dx.doi.org/10.1484/M.CORN.1.101554

Ufkes, T. 1984. De Kerstvloed van 1717: oorzaken en gevolgen van een natuurramp. Dissertation. University of Groningen, Groningen, The Netherlands.

van Bavel, B. 1993. Goederenverwerving en goederenbeheer van de abdij Mariënweerd (1129-1592). Verloren, Hilversum, The Netherlands.

van Bavel, B. 1999. Transitie en continuïteit: de bezitsverhoudingen en de plattelands-economie in het westelijk gedeelte van het Gelderse rivierengebied ( ca 1300-ca. 1570). Verloren, Hilversum, The Netherlands.

van Bavel, B. 2001. Land, lease and agriculture: the transition of the rural economy in the Dutch river area from the fourteenth to the sixteenth century. Past \& Present 172(1):3-43. http://dx.doi. org/10.1093/past/172.1.3

van Bavel, B. 2004. The land market in the North Sea area in a comparative perspective, $13^{\text {th }}-18^{\text {th }}$ centuries. Pages $119-146$ in $\mathrm{S}$. Cavaciocchi, editor. Il mercato della terra secc. XIII-XVIII. Le Monnier, Bagno a Ripoli, Italy.

van Bavel, B. 2010. Manors and markets: economy and society in the Low Countries, 500-1600. Oxford University Press, Oxford, UK. http://dx.doi.org/10.1093/acprof:oso/9780199278664.001.0001

van Bavel, B. 2015. History as a laboratory to better understand the formation of institutions. Journal of Institutional Economics 11(1):69-91. http://dx.doi.org/10.1017/S1744137414000216 
van Bavel, B., and D. R. Curtis. 2016. Better understanding disasters by better using history: systematically using the historical record as one way to advance research into disasters. International Journal of Mass Emergencies and Disasters 34 (1):143-69.

van Besouw, B., and D. R. Curtis. 2018. Death at a distance? Warfare and mortality in the seventeenth-century Low Countries. Economic History Association Annual Meeting, Montreal, Canada, September 7-9. [online] URL: http://eh.net/eha/wpcontent/uploads/2018/06/Besouw.pdf

van Cruyningen, P. 2014. From disaster to sustainability: floods, changing property relations and water management in the southwestern Netherlands, c.1500-1800. Continuity and Change 29 (2):241-265. http://dx.doi.org/10.1017/S0268416014000149

van Tielhof, M. 2015. Forced solidarity: maintenance of coastal defences along the North Sea coast in the early modern period. Environment and History 21(3):319-350. http://dx.doi. org/10.3197/096734015X14345369355746

Vermue, A. F. 2012. Noordbroek: een interdisciplinair onderzoek naar de vorming en ingebruikname van de kleilanden in de $15^{\text {de }}$ en $16^{\text {de }}$ eeuw. Thesis. University of Groningen, Groningen, The Netherlands.

Vervaet, L. 2015. Goederenbeheer in een veranderende samenleving: het Sint-Janshospitaal van Brugge, ca. 1275-ca. 1575. Dissertation. University of Ghent, Ghent, Belgium.

Walker, B., C. S. Holling, S. R. Carpenter, and A. Kinzig. 2004. Resilience, adaptability and transformability in social-ecological systems. Ecology and Society 9(2):5. http://dx.doi.org/10.5751/ ES-00650-090205

Wetter, O., C. Pfister, R. Weingartner, J. Luterbacher, T. Reist, and J. Trösch. 2011. The largest floods in the High Rhine basin since 1268 assessed from documentary and instrumental evidence. Hydrological Sciences Journal 56(5):733-758. http://dx.doi. org/10.1080/02626667.2011.583613 